See discussions, stats, and author profiles for this publication at: https://www.researchgate.net/publication/310620742

\title{
Performance and methane emissions of grazing nellore bulls supplemented with crude glycerin
}

Article $\cdot$ November 2016

DOI: 10.2527/jas2016-0530

\section{CITATION}

1

8 authors, including:

$$
\text { Elias San Vito }
$$

São Paulo State University

31 PUBLICATIONS 85 CITATIONS

SEE PROFILE

Rosa Frighetto

Brazilian Agricultural Research Corporation (EMBRAPA)

48 PUBLICATIONS 858 CITATIONS

SEE PROFILE
READS

91

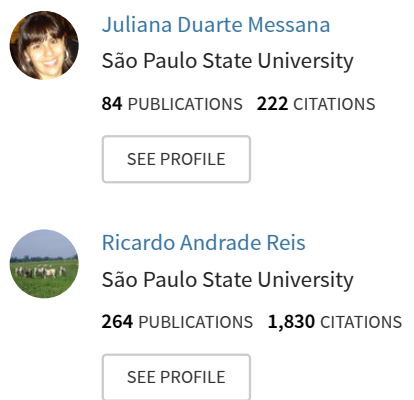

Some of the authors of this publication are also working on these related projects:

Project Studies about silage View project

Project MANAGEMENT STRATEGIES TO REDUCE ENVIRONMENTAL IMPACTS OF BEEF CATTLE PRODUCTION SYSTEMS. Projeto FAPESP. View project 


\title{
Performance and methane emissions of grazing Nellore bulls supplemented with crude glycerin ${ }^{1}$
}

\author{
E. San Vito,*2 J. F. Lage,* J. D. Messana,* E. E. Dallantonia,* \\ R. T. S. Frighetto, $\dagger$ R. A. Reis, $* \$ \S$ A. J. Neto, ${ }^{*}$ and T. T. Berchielli* $* \S$ \\ *Department of Animal Science, College of Agrarian and Veterinarian Sciences, São Paulo State University, \\ Via de Acesso Professor Paulo Donato Castellane, s/n, Jaboticabal, SP 14884-900, Brazil; †Embrapa Environment, \\ Rodovia Campinas, Mogi-Mirim km 127, Tanquinho Velho, Jaguariúna, SP 13820-000, Brazil; †Instituto Nacional de \\ Ciência e Tecnologia/Ciência Animal, Viçosa, Minas Gerais, Brazil; and §CNPq, Estrada Parque Dom Bosco, Brasillia, Brazil
}

\begin{abstract}
Supplementation of grass-fed cattle with low-cost feeding alternatives may be an attractive way to improve efficiency of cattle production. We hypothesized that inclusion of crude glycerin (CG) in supplements provided to grass-fed cattle could improve feed conversion without negative effects on growth performance while reducing methane emissions. Our hypothesis was tested using Nellore bulls grazing tropical pasture $(n=50$; initial $\mathrm{BW}$ of $427 \pm$ $19.41 \mathrm{~kg}$; age of $17 \pm 2 \mathrm{mo}$ ) supplemented with increasing concentrations $(0,70,140,210$, and $280 \mathrm{~g}$ / $\mathrm{kg}$ DM basis of supplement) of CG and corn gluten replacing corn grain. A second experiment was conducted using 10 ruminally cannulated Nellore steers ( $490.1 \pm 47.8 \mathrm{~kg} \mathrm{BW}$; age of $25 \mathrm{mo}$ ) to assess the impact of different concentrations of glycerin in the supplement on ruminal VFA concentration. Inclusion of CG did not affect total DMI $(P=0.53)$, DMI of forage $(P=0.41)$, supplement DMI $(P=0.47)$, organic matter intake $(P=0.50)$, crude protein intake $(P=$ $0.24)$, NDF intake $(P=0.49)$, GE intake $(P=0.50)$,
\end{abstract}

NDF digestibility $(P=0.17)$, final BW $(P=0.17)$, LM area $(P=0.50)$, rib fat thickness $(P=0.87)$, or carcass gain $(P=0.13)$. The inclusion of $C G$ in the supplement linearly increased $(P<0.001)$ the molar proportion of propionate, butyrate, and valerate; linearly decreased acetate $(P=0.001)$; and did not affect the molar proportion of isovalerate $(P=0.31)$ and isobutyrate $(P=$ $0.63)$, thereby reducing the acetate to propionate ratio $(P<0.001)$. The increase of CG supplementation of young bulls in pasture had a quadratic effect on BW gain $(P=0.002)$, with lower BW gain with $140 \mathrm{~g} / \mathrm{kg}$ DM of CG in the supplement and tended $(P=0.06)$ to improve $\mathrm{G}$ :F. Inclusion of $\mathrm{CG}$ did not affect ruminal $\mathrm{CH}_{4}$ emission expressed in kilograms per year $(P=0.74)$, grams per kilogram of DMI $(P=0.69)$, and grams per kilogram of carcass gain $(P=0.48)$. Crude glycerin supplementation was not effective as a strategy to reduce $\mathrm{CH}_{4}$ emission in grass-fed cattle. However, CG can be effectively used as a partial energy source in supplement of grazing cattle, promoting an improvement in feed efficiency.

Keywords: biodiesel coproducts, cattle, forage, glycerol, greenhouse gas

(C) 2016 American Society of Animal Science. All rights reserved.

\footnotetext{
${ }^{1}$ We thank the São Paulo Research Foundation (FAPESP), grant numbers 2011/06409-2 and 2011/00060-8, for supporting this work; Cargill for providing feed supplies for experimental diets; and Minerva Foods for their collaboration during the experimental slaughter. The authors also wish to acknowledge the students of the Digestibility and Ruminant Food Evaluation Center of FCAVUNESP for their support during this experiment.

${ }^{2}$ Corresponding author: esanvito@zootecnista.com.br

Received August 30, 2016.

Accepted September 8, 2016.
}

J. Anim. Sci. 2016.94:4728-4737 doi:10.2527/jas2016-0530

\section{INTRODUCTION}

The increased use of corn grain in biofuel production led to a rise in the cost of these feedstuffs (ActionAid International USA, 2012). Therefore, the cattle feeding industry is searching for alternatives to reduce costs of grain while meeting the demand for meat quality with minimal environmental impact. The use of supplements for grazing cattle is a tool 
to maximize animal performance, increase the meat production per unit of area, improve meat and carcass quality, and shorten the finishing period of grazing cattle (Reis et al., 2009). Thus, supplementation of grass-fed beef with low-cost feeding alternatives may be an attractive way to improve efficiency of cattle production and reduce environmental impacts.

In addition, there is growing pressure on the beef cattle industry to reduce the negative environmental impacts, which accounts for $65 \%$ of livestock greenhouse gas emissions and $42.6 \%$ of $\mathrm{CH}_{4}$ emissions (Gerber et al., 2013). In addition, worldwide, $\mathrm{CH}_{4}$ represents energy loss from animal production that equates to approximately $6.5 \%$ in pasture animals receiving diets with less than $90 \%$ concentrate (Intergovernmental Panel on Climate Change, 2006). An alternative to mitigate $\mathrm{CH}_{4}$ emission from grazing cattle is the inclusion of crude glycerin (CG) in the supplement (Boadi et al., 2004; McAllister and Newbold, 2008).

Crude glycerin is a by-product of biodiesel and has been increasingly used as a feed ingredient to replace grain in feedlot beef cattle diets as a viable energy source (Mach et al., 2009; Parsons et al., 2009; Hales et al., 2013). The CG can be absorbed directly by the ruminal epithelium and can then be converted to glucose in the liver (Krehbiel, 2008) or fermented in the rumen, mainly to propionate (Wang et al., 2009). Moreover, it has been proposed to act as a hydrogen sink as a means of reducing $\mathrm{CH}_{4}$ emissions (Boadi et al., 2004).

Our hypothesis is that CG can be included to replace corn grain in the supplement of beef cattle fed grass-based diets, which will decrease ruminal $\mathrm{CH}_{4}$ emission without compromising animal performance. Therefore, our objective was to investigate these effects on pasture-raised young Nellore cattle supplemented with increasing CG concentrations.

\section{MATERIALS AND METHODS}

The protocol used in this experiment was in accordance with the Brazilian College of Animal Experimentation(Colégio Brasileiro de Experimentação Animal) guidelines and was approved by the Ethics, Bioethics, and Animal Welfare Committee (Comissão de Ética e Bem Estar Animal) of the Faculdade de Ciências Agrárias e Veterinárias, Universidade Estadual Paulista (UNESP; protocol number 021119/11).

\section{Animals and Management}

Fifty Nellore bulls were used, with an average age of $17 \pm 2 \mathrm{mo}$ and an initial BW of $427 \pm 19.4 \mathrm{~kg}$. Initially, animals were weighed, identified, and subjected to endo- and ectoparasite treatments utilizing ivermectin (Ivomec Injetável, $200 \mathrm{mg} / \mathrm{kg}$, Merial Brasil, Campinas, SP, Brazil) and allocated in 10 paddocks of Brachiaria brizantha $\mathrm{cv}$. Xaraés permanent grassland.

Diets consisted of $0,70,140,210$, and $280 \mathrm{~g} / \mathrm{kg} \mathrm{DM}$ inclusion of $C G$ in the supplement. Levels used were based on the maximum amount of CG that we could use without causing problems in the mixture, storage, and supply of the supplement to the animals. Crude glycerin $(870.9 \mathrm{~g} / \mathrm{kg} \mathrm{DM}, 50.7 \mathrm{~g} / \mathrm{kg}$ mineral matter, $10.1 \mathrm{~g} / \mathrm{kg} \mathrm{CP}$, $10.8 \mathrm{~g} / \mathrm{kg}$ ether extract [EE], $800.3 \mathrm{~g} / \mathrm{kg}$ glycerol, $0.3 \mathrm{~g} /$ $\mathrm{kg}$ methanol) was acquired from a soybean oil-based biodiesel production company (ADM, Rondonópolis, MT, Brazil). Supplemental corn gluten was added with increasing $C G$ to keep diets isonitrogenous. Ingredients were sampled every $15 \mathrm{~d}$ to determine the chemical composition (Table 1). Performance animals were distributed in a complete randomized design into ten 1.8-ha paddocks (experimental unit) with 5 animals per paddock and 2 paddocks per treatment. Bulls were group supplemented at $300 \mathrm{~g} / 100 \mathrm{~kg} \mathrm{BW}$ daily at $1000 \mathrm{~h}$ in collective covered feed bunks arranged in each paddock. Each paddock contained an automatic 1,000-L metal water trough.

The experiment was conducted during the rainy season at UNESP in Jaboticabal, São Paulo, Brazil $\left(48^{\circ} 18^{\prime} \mathrm{W}, 21^{\circ} 15^{\prime} \mathrm{S}\right.$, altitude $\left.595 \mathrm{~m}\right)$ from December 2011 to May 2012. Under the international Köppen classification, this climate in characterized as tropical type Aw with summer rains and a relatively dry winter. During the experimental period, the average monthly precipitation was $59.93 \mathrm{~mm}$, with an average maximum monthly temperature of $33.5^{\circ} \mathrm{C}$ and average minimum monthly temperature of $14.5^{\circ} \mathrm{C}$. The experimental period lasted $142 \mathrm{~d}$, divided into five 28 -d periods.

A continuous grazing method with variable stocking rate ("put and take" stocking) was utilized (Allen et al., 2011), with the use of regulator animals, with the objective to maintain sward height at $30 \mathrm{~cm}$. Control of the stocking rate was done weekly as a function of the predetermined forage heights; that is, when the height was greater than $30 \mathrm{~cm}$, animals were added, and in the inverse situation, animals were removed.

Forage height was randomly measured weekly at 80 points using a graduated stick in each paddock (Barthram, 1985). Samples to address herbage chemical composition were obtained by hand plucking (Johnson, 1978). Hand plucking was performed on the same days as the estimation of DMI (described later). The plucking of herbage per paddock was performed every $28 \mathrm{~d}$.

Every $28 \mathrm{~d}$ the animals were weighed without fasting to adjust the quantity of supplement offered. Individual BW was recorded at the beginning and end of the study after a 16-h withdrawal period from feed and water. Feed efficiency was calculated as the ratio between kilograms of ADG and kilograms of DMI ( $\mathrm{kg} \mathrm{BW}$ gain $/ \mathrm{kg}$ DMI). 
Table 1. Ingredients and chemical composition of supplements and pasture of Brachiaria brizantha cv. Xaraés

\begin{tabular}{|c|c|c|c|c|c|c|}
\hline \multirow[b]{2}{*}{ Item } & \multicolumn{5}{|c|}{ Crude glycerin in supplement, g/kg DM } & \multirow[b]{2}{*}{ Pasture $^{1}$} \\
\hline & 0 & 70 & 140 & 210 & 280 & \\
\hline \multicolumn{7}{|l|}{ Ingredients, $\%$ of DM } \\
\hline Corn grain & 50 & 41 & 33.2 & 25.3 & 17.5 & - \\
\hline Crude glycerin & 0 & 7 & 14 & 21 & 28 & - \\
\hline Corn gluten & 0 & 2 & 2.8 & 3.7 & 4.5 & - \\
\hline Soybean meal & 42 & 42 & 42 & 42 & 42 & - \\
\hline Urea/ammonium sulfate & 3 & 3 & 3 & 3 & 3 & - \\
\hline Mineral mix ${ }^{2}$ & 5 & 5 & 5 & 5 & 5 & - \\
\hline \multicolumn{7}{|l|}{ Chemical composition } \\
\hline DM, \% & 91.1 & 91.1 & 91.0 & 91.0 & 91.0 & $90.0 \pm 0.37$ \\
\hline $\mathrm{CP}, \% \mathrm{DM}$ & 37.1 & 37.1 & 37.1 & 37.0 & 37.0 & $12.1 \pm 0.67$ \\
\hline NDF, \% DM & 14.0 & 13.0 & 12.0 & 10.1 & 9.1 & $59.1 \pm 1.44$ \\
\hline Ether extract, \% DM & 3.1 & 3.1 & 3.0 & 2.1 & 2.1 & $1.0 \pm 0.12$ \\
\hline $\mathrm{NFC}, 3 \% \mathrm{DM}$ & 40.1 & 41.1 & 43.0 & 44.0 & 45.1 & $19.0 \pm 1.15$ \\
\hline
\end{tabular}

${ }^{1}$ Average and SD of the mean of samples obtained by the simulated grazing technique in 5 periods.

${ }^{2}$ Composition = calcium: $210 \mathrm{~g} / \mathrm{kg}$; phosphorus: $20 \mathrm{~g} / \mathrm{kg}$; sulfur: $37 \mathrm{~g} / \mathrm{kg}$, sodium: $80 \mathrm{~g} / \mathrm{kg}$; copper: $490 \mathrm{mg} / \mathrm{kg}$, manganese: $1.424 \mathrm{mg} / \mathrm{kg}$, zinc: $1.830 \mathrm{mg} /$ $\mathrm{kg}$, iodine: $36 \mathrm{mg} / \mathrm{kg}$; cobalt: $29 \mathrm{mg} / \mathrm{kg}$, selenium: $9 \mathrm{mg} / \mathrm{kg}$; fluorine (maximum): $333 \mathrm{mg} / \mathrm{kg}$.

${ }^{3} \mathrm{NFC}=$ nonfibrous carbohydrates: Calculated as $100-(\mathrm{CP}+$ ether extract + ash $+\mathrm{NDF})$.

After $142 \mathrm{~d}$ of feeding, all the animals were slaughtered at a commercial beef packing plant with $550 \pm$ $30.6 \mathrm{~kg}$ of shrunk BW. Preslaughtering handling was in accordance with good animal welfare practices, and slaughtering procedures followed the Sanitary and Industrial Inspection Regulation for Animal Origin Products (Ministério da Agricultura, Pecuária e Abastecimento, 1997). After slaughter, carcasses were weighed and refrigerated at $4^{\circ} \mathrm{C}$ for approximately 24 $\mathrm{h}$. The cold carcass weight was then recorded. After the postmortem chill period, the 12th rib fat thickness (RFT) and 12th rib LM area were measured on the left side of each carcass between the 12th and 13th ribs. Longissimus muscle areas were traced on transparencies and measured later with a planimeter (Greiner et al., 2003). Carcass gain (CrG) was determined via the comparative slaughter technique. Five animals $(415.6 \pm 39.8 \mathrm{~kg})$ were selected as a reference group and slaughtered to obtain the dressing percentage (DP; $54 \%$ ) on d 0 of the experiment. These animals were selected by the average weight of the whole group. The DP of the reference group was used in conjunction with initial BW (d 0) of 50 animals to estimate the initial carcass weight $(\mathbf{C W i}): \mathrm{CWi}=(\mathrm{BWi} \times \mathrm{DP}$ of reference group)/100. Therefore, $\mathrm{CrG}$ was calculated for each animal using the difference between the final carcass weight (CWf) and CWi, divided by the number of days in feeding $(\mathrm{CrG}=[\mathrm{CWf}-\mathrm{CWi}] /$ days of feeding $)$.

In addition to the performance study, 10 ruminally cannulated (rubber rumen cannula 4", KEHL, São Carlos, Brazil) Nellore steers (490.1 $\pm 47.8 \mathrm{~kg}$ of BW) at $25 \pm 2$ mo of age were utilized in a metabolism study. Specifically, animals were allocated into 5 paddocks (2 animals per paddock) of 0.25 ha each and distributed in a replicated $5 \times 5$ Latin square arrangement to assess the impact of different concentrations of glycerin in the supplement on ruminal concentration of VFA. Each period consisted of $10 \mathrm{~d}$ for adaptation to the supplement and $1 \mathrm{~d}$ for sampling. Steers were individually supplemented at the rate of $300 \mathrm{~g} / 100 \mathrm{~kg} \mathrm{BW}$ daily at $1000 \mathrm{~h}$.

\section{Chemical Analysis}

For chemical analysis, samples of ingredients, forage, and feces were dried at $55^{\circ} \mathrm{C}$ for $72 \mathrm{~h}$. Samples were then ground in a Wiley mill (Thomas model 4 Wiley Mill; Thomas Scientific, Swedesboro, NJ) to pass through a 1-mm screen and analyzed for DM (method 934.01), OM (method 942.05), and EE (method 920.85) in accordance with the Association of Official Analytical Chemists (AOAC; AOAC 1995). Concentrations of $\mathrm{N}$ in each sample were determined by rapid combustion $\left(850^{\circ} \mathrm{C}\right)$, conversion of all $\mathrm{N}$ combustion products to $\mathrm{N}_{2}$, and subsequent measurement by using a LECO cell thermoconductivity device (model FP-528; LECO Corp., St. Joseph, MI). The GE content of supplements and forage was determined using an adiabatic bomb calorimeter (model 6300, Parr Instrument Co., Moline, IL). Analyses for NDF were conducted following Van Soest et al. (1991) and adapted for an Ankom 200 Fiber Analyzer (Ankom Inc., Fairport, NY) with ash correction. Heat-stable $\alpha$-amylase was included in the NDF solution, without added sodium sulfite. The amount of nonfibrous carbohydrates (NFC) was determined as described by Hall 
(2000), and TDN was calculated according to NRC (2001).

\section{Ruminal Fermentation}

Rumen VFA was measured in the ruminally cannulated animals on $\mathrm{d} 11$ of each period. Aliquots of 50 $\mathrm{mL}$ of ruminal contents were obtained at $0,3,6,12$, and $18 \mathrm{~h}$ after $1000 \mathrm{~h}$ supplementation. Rumen fluid was obtained from several sites within the rumen and was subsequently strained through 2 layers of cheesecloth.

Samples collected were centrifuged at $13,000 \times g$ $\left(4^{\circ} \mathrm{C}\right)$ for $30 \mathrm{~min}$ and quantified by gas chromatography (GC2014, Shimatzu Corporation, Kyoto, Japan) with an HP-INNOWax capillary column $(30 \mathrm{~m} \times 0.32 \mathrm{~mm}$; 0.50- $\mu \mathrm{m}$ film thickness; Agilent Technologies, Santa Clara, CA) at an initial temperature of $80^{\circ} \mathrm{C}$ and a final temperature of $240^{\circ} \mathrm{C}$.

\section{Intake Estimation}

Thirty animals were used to estimate intake and nutrient digestibility. Lignin isolated, purified, and enriched from Eucalyptus grandis (LIPE) and indigestible NDF (iNDF) were used to estimate the excretion of fecal matter (as dry weight) and forage intake, respectively.

A 500-mg LIPE capsule was provided for $8 \mathrm{~d}$ by oral administration, with $5 \mathrm{~d}$ to stabilize fecal excretion of the marker and sample collection in the last $3 \mathrm{~d}$ (Santos et al., 2011). Fecal samples were collected during 3 d, directly from the rectum, at 1600 and 1100, 1500 and 0900, and 1400 and $0700 \mathrm{~h}$ on the first, second, and third days of collection, respectively, to obtain representative samples. Fecal samples were dried at $55^{\circ} \mathrm{C}$ for $72 \mathrm{~h}$ and ground in a Wiley mill (Thomas Scientific) to pass through a 1-mm screen and composited proportionately on each of the $3 \mathrm{~d}$ of sampling, within each animal, based on fecal dry weights. Approximately $10 \mathrm{~g}$ of each composite sample of feces were sent to the Federal University of Minas Gerais (Belo Horizonte, MG, Brazil) to analyze the lignin marker concentration using the infrared spectroscopy method (Saliba et al., 2013).

The individual intake of forage was estimated using the internal marker iNDF. The samples of feces, forage, and concentrate were placed in ANKOM bags (filter bag F57; ANKOM Technology Corp., Macedon, NY) and incubated in the rumen of a cannulated Nellore animal for a period of $288 \mathrm{~h}$ (Valente et al., 2011). When the bags were withdrawn from the rumen, they were soaked in water for 30 min and gently washed by hand under running water until the wash water ran clear. Then, bags were analyzed for NDF concentration using an Ankom 200 Fiber Analyzer, and the iNDF was determined by weighing the bags with a digital scale after drying in an oven, first at $50^{\circ} \mathrm{C}$ for $72 \mathrm{~h}$, followed by $105^{\circ} \mathrm{C}$ for $12 \mathrm{~h}$. The residue was considered the iNDF. Individual forage intakes were estimated by subtracting the marker extraction from concentrate from the total iNDF excretion and dividing that difference by the concentration of the marker in the forage.

Individual concentrate (supplement) intake was estimated by dividing the total concentrate provided by the number of animals in each paddock.

\section{Methane Measurements}

Sulfur hexafluoride $\left(\mathbf{S F}_{\mathbf{6}}\right.$ ), a tracer method for measuring eructated $\mathrm{CH}_{4}$, was used in this study (Johnson et al., 1994), in which each animal was sampled daily for 6 consecutive 24-h days, beginning on $\mathrm{d}$ 130 of feeding. Thirty animals were fitted with gas collection halters $14 \mathrm{~d}$ before methane sampling to allow animal acclimation facilitate sampling. The selection criterion utilized was the animal's tameness and ease of handling in the management center. The enteric methane was measured simultaneously in animals.

A small brass permeation tube, with a known $\mathrm{SF}_{6}$ permeation rate, was placed in the reticulum $72 \mathrm{~h}$ before sample collection to allow tracer gas to equilibrate in the rumen. Eructated gas samples were continuously obtained through a capillary tube connected to a collection canister placed on the neck of the animal.

A halter with $0.127-\mathrm{mm}$ stainless-steel capillary tubing and an in-line $15-\mu \mathrm{m}$ filter was placed on the animal's head and connected to an evacuated sampling canister. Collection PVC pipe canisters were attached to a vacuum pump in the laboratory to create a negative pressure of $<6.9 \times 10^{3} \mathrm{~Pa}(-0.07 \mathrm{~atm})$. As the vacuum in the sampling canister was slowly dissipated, the negative pressure steadily drew the air sample from around the mouth and nose of the animal. Additional canisters were placed near the experimental pasture to monitor background concentration of $\mathrm{CH}_{4}$ and $\mathrm{SF}_{6}$ daily during each sampling period. Sampling started daily at $0700 \mathrm{~h}$ when animals were removed from the paddocks and moved to working facility for sampling.

After sample collection and pressuring the canister with $\mathrm{N}, \mathrm{CH}_{4}$ and $\mathrm{SF}_{6}$ in the collection tubes were measured at Embrapa Meio Ambiente (Jaguariúna, SP, Brazil) using gas chromatography (Hewlett-Packard Agilent 6890, Agilent Technologies). The $\mathrm{CH}_{4}$ flux produced by animals was calculated as the $\mathrm{SF}_{6}$ tracer gas flux from a permeation capsule placed in the rumen minus the basal $\mathrm{CH}_{4}$ concentration in the air (Westberg et al., 1998). The following equation was used:

$$
\mathrm{Q}_{\mathrm{CH} 4}=\mathrm{Q}_{\mathrm{SF} 6}\left[\left(\mathrm{CH}_{4}\right)_{\mathrm{y}}-\left(\mathrm{CH}_{4}\right)_{\mathrm{b}}\right] /\left(\mathrm{SF}_{6}\right) \text {, }
$$


Table 2. Effect of supplements containing different crude glycerin (CG) concentration on intake and coefficient of total tract apparent digestibility of young Nellore bulls in pasture

\begin{tabular}{|c|c|c|c|c|c|c|c|c|c|}
\hline \multirow[b]{3}{*}{ Item } & \multicolumn{5}{|c|}{ CG in the supplement, $\mathrm{g} / \mathrm{kg} \mathrm{DM}$} & \multirow[b]{3}{*}{ SEM } & \multicolumn{3}{|c|}{$P$-value } \\
\hline & \multirow[b]{2}{*}{0} & \multirow[b]{2}{*}{70} & \multirow[b]{2}{*}{140} & \multirow[b]{2}{*}{210} & \multirow[b]{2}{*}{280} & & \multirow[b]{2}{*}{ Supplement } & \multicolumn{2}{|c|}{ Contrast $^{1}$} \\
\hline & & & & & & & & $\mathrm{L}$ & Q \\
\hline \multicolumn{10}{|l|}{ Intake, $\mathrm{kg} / \mathrm{d}$} \\
\hline $\mathrm{DM}$ & 11.19 & 11.08 & 10.41 & 10.37 & 10.97 & 0.99 & 0.53 & 0.40 & 0.21 \\
\hline Forage DM & 9.17 & 9.47 & 8.59 & 8.73 & 8.80 & 0.85 & 0.41 & 0.19 & 0.67 \\
\hline Supplement DM & 2.01 & 1.61 & 1.81 & 1.64 & 2.17 & 0.58 & 0.47 & 0.66 & 0.12 \\
\hline $\mathrm{OM}$ & 10.33 & 10.23 & 9.58 & 9.54 & 10.09 & 0.92 & 0.50 & 0.36 & 0.21 \\
\hline $\mathrm{CP}$ & 1.99 & 1.66 & 1.83 & 1.67 & 1.86 & 0.25 & 0.24 & 0.47 & 0.11 \\
\hline $\mathrm{NDF}$ & 5.86 & 6.14 & 5.55 & 5.75 & 5.77 & 0.51 & 0.49 & 0.41 & 0.76 \\
\hline $\mathrm{GE}, \mathrm{MJ} / \mathrm{d}$ & 204.7 & 201.3 & 190.5 & 190.4 & 191.0 & 22.6 & 0.50 & 0.31 & 0.28 \\
\hline \multicolumn{10}{|l|}{ Digestibility, \% DM } \\
\hline $\mathrm{DM}$ & 59.9 & 58.6 & 56.6 & 57.0 & 59.1 & 3.4 & 0.49 & 0.51 & 0.11 \\
\hline $\mathrm{OM}$ & 65.0 & 62.9 & 59.9 & 60.4 & 62.6 & 3.8 & 0.23 & 0.18 & 0.06 \\
\hline $\mathrm{CP}$ & 70.3 & 64.9 & 65.9 & 64.4 & 68.5 & 4.6 & 0.21 & 0.53 & 0.03 \\
\hline $\mathrm{NDF}$ & 61.0 & 60.7 & 56.2 & 55.9 & 56.0 & 4.6 & 0.17 & 0.03 & 0.24 \\
\hline TDN & 61.9 & 59.3 & 56.8 & 57.1 & 59.2 & 3.9 & 0.23 & 0.16 & 0.06 \\
\hline
\end{tabular}

${ }^{1}$ Contrasts: $\mathrm{L}=$ linear, $\mathrm{Q}=$ quadratic.

where $\mathrm{Q}_{\mathrm{CH} 4}=\mathrm{CH}_{4}$ emission rate by animal, $\mathrm{QSF}_{6}=$ known $\mathrm{SF}_{6}$ emission rate from capsule in rumen, $\left(\mathrm{CH}_{4}\right) \mathrm{y}=\mathrm{CH}_{4}$ concentrations in collection apparatus, $\left(\mathrm{CH}_{4}\right) \mathrm{b}=$ basal $\mathrm{CH}_{4}$ concentration, and $\left(\mathrm{SF}_{6}\right)=\mathrm{SF}_{6}$ concentration in collection apparatus.

Methane emissions $\left(\mathrm{g} \cdot \mathrm{animal}^{-1} \cdot \mathrm{d}^{-1}\right.$ and $\mathrm{kg} \cdot$ animal $^{-1} \cdot \mathrm{yr}^{-1}$ ) and grams of methane per kilogram of DMI, kilograms of digestible NDF intake ( $\mathrm{g} / \mathrm{kg}$ ), and percentage of GE intake (MJ/d) were calculated by dividing the daily methane output of each animal by daily intake (during methane sampling), whereas methane emissions $\left(\mathrm{g} \cdot\right.$ animal $\left.^{-1} \cdot \mathrm{d}^{-1}\right)$ were calculated in relation to kilograms of $\mathrm{CrG}$ (throughout the entire experimental period).

\section{Statistical Analysis}

Data were analyzed as a completely randomized experimental design by using the GLM procedure of SAS (SAS Inst. Inc., Cary, NC). Paddock was the experimental unit, and the model effects included treatment. Initial BW was used as a covariate for the statistical analysis of ADG. Homogeneity of the data was verified using the UNIVARIATE procedure of SAS. Studentized residuals were plotted against the predicted values using the plot procedure to analyze data for outliers. The LSMEANS statement of the mixed procedure of SAS was used to calculate mean values. Orthogonal contrasts were used to determine the linear and quadratic effects of glycerin treatment, with significance considered at $P<0.05$.

The experimental design used for the evaluations of ruminal fermentation parameters was analyzed in a replicated $5 \times 5$ Latin square with 5 supplement sources, 10 animals, and 5 experimental periods. Statistical model included the fixed effect of treatment and random effects of Latin square, period, animal (period), and the error. Linear, quadratic, cubic, and quartic effects of CG levels were tested with orthogonal contrasts using the contrast option of the MIXED procedure of SAS. Cubic and quartic effects were not significant $(P>0.05)$. Statistical evaluations of VFA were analyzed as repeated measurements.

\section{RESULTS}

Pasture supplementation with $\mathrm{CG}$ did not affect intake of total DM $(P=0.53)$, forage $(P=0.41)$ and supplement $(P=0.47), \mathrm{OM}(P=0.50), \mathrm{CP}(P=0.24)$, NDF $(P=0.49)$, and GE $(P=0.50)$. Inclusion of $C G$ in the supplements did not affect the digestibility of $\mathrm{DM}(P=0.49)$ and nutrients: $\mathrm{OM}(P=0.23), \mathrm{CP}(P=$ $0.21)$, NDF $(P=0.17)$, and TDN $(P=0.23$; Table 2$)$.

The increase of CG supplementation of young bulls in pasture did not affect final BW $(P=0.17), \mathrm{LM}$ area $(P=0.50)$, RFT $(P=0.87)$, and $\mathrm{CrG}(P=0.13)$. However, increased concentration of $C G$ supplementation showed a linear effect $(P=0.03)$ with a tendency $(P=0.06)$ to increase $\mathrm{G}: \mathrm{F}$. Inclusion of $\mathrm{CG}$ in the supplement increased $\operatorname{ADG}(P=0.01)$, showing a quadratic effect $(P=0.002)$, presenting a lower BW gain for $140 \mathrm{~g} / \mathrm{kg} \mathrm{DM}$ and a higher value for $210 \mathrm{~g} / \mathrm{kg}$ of CG inclusion (Table 3 ).

Inclusion of CG did not affect total ruminal VFA concentration $(P=0.29)$ or the molar proportion of isobutyrate $(P=0.63)$ and isovalerate $(P=0.31)$. However, the increase of CG levels in the supplement linearly increased the molar proportion of propionate 
Table 3. Effect of supplements containing different crude glycerin (CG) concentrations on performance of young Nellore bulls in pasture

\begin{tabular}{|c|c|c|c|c|c|c|c|c|c|}
\hline \multirow[b]{3}{*}{ Item } & \multicolumn{5}{|c|}{ CG in the supplement, $\mathrm{g} / \mathrm{kg} \mathrm{DM}$} & \multirow[b]{3}{*}{ SEM } & \multicolumn{3}{|c|}{$P$-value } \\
\hline & \multirow[b]{2}{*}{0} & \multirow[b]{2}{*}{70} & \multirow[b]{2}{*}{140} & \multirow[b]{2}{*}{210} & \multirow[b]{2}{*}{280} & & \multirow[b]{2}{*}{ Supplement } & \multicolumn{2}{|c|}{ Contrast $^{1}$} \\
\hline & & & & & & & & $\mathrm{L}$ & $\mathrm{Q}$ \\
\hline Initial BW, kg & 425.2 & 427.9 & 423.7 & 425.2 & 428.6 & 17.11 & 0.97 & 0.41 & 0.26 \\
\hline Final BW, kg & 548.2 & 553.7 & 527.4 & 553.2 & 557.3 & 27.50 & 0.17 & 0.21 & 0.09 \\
\hline $\mathrm{ADG}, \mathrm{kg} / \mathrm{d}$ & 0.872 & 0.892 & 0.735 & 0.930 & 0.912 & 0.124 & 0.01 & 0.20 & 0.002 \\
\hline $\mathrm{G}: \mathrm{F}$ & 0.075 & 0.073 & 0.070 & 0.095 & 0.086 & 0.012 & 0.06 & 0.03 & 0.54 \\
\hline $\mathrm{CrG},{ }^{2} \mathrm{~kg} / \mathrm{d}$ & 0.53 & 0.55 & 0.47 & 0.57 & 0.53 & 0.076 & 0.13 & 0.68 & 0.48 \\
\hline $\mathrm{LM}$ area, $\mathrm{cm}^{2}$ & 83.14 & 84.26 & 83.57 & 88.69 & 82.60 & 7.823 & 0.50 & 0.68 & 0.37 \\
\hline $\mathrm{RFT},{ }^{3} \mathrm{~mm}$ & 3.04 & 2.99 & 2.66 & 2.99 & 2.94 & 0.817 & 0.87 & 0.82 & 0.52 \\
\hline
\end{tabular}

$(P=0.001)$, butyrate $(P=0.001)$, and valerate $(P=$ $0.001)$. The inclusion of $C G$ in the supplement linearly decreased the molar proportion of acetate $(P=0.001)$, consequently decreasing the acetate to propionate ratio $(P<0.001$; Table 4$)$.

Inclusion of $\mathrm{CG}$ in the supplement did not affect ruminal $\mathrm{CH}_{4}$ emissions, expressed in grams per day and kilograms per year $(P=0.74$; Table 5$)$. Also, inclusion of $\mathrm{CG}$ in the supplement did not affect $\mathrm{CH}_{4}$ emission when expressed in grams per kilogram of DMI $(P=0.69)$, grams per kilogram of digestible NDF intake $(P=0.42)$, percentage of GE intake $(P=0.76)$, or grams per kilogram of $\mathrm{CrG}(P=0.48)$.

\section{DISCUSSION}

Replacement of corn grain with CG as a diet supplement for young Nellore bulls did not change intake of nutrients measured. This observation may be explained by the fact that the ingested amounts of CG did not exceed $55.6 \mathrm{~g} / \mathrm{kg}$ DM diet, which is less than the CG concentration (120 g/ $/ \mathrm{kg}$ DM) established by Mach et al. (2009) and Parsons et al. (2009) to cause decreased intake in cattle. Increase of production and absorption of propionate in the rumen can be related to a depression of diet intake in ruminants (Allen and Bradford, 2009). However, even with the increase of the molar proportion of propionate in the rumen, the concentrations of propionate were not sufficient to act on receptors present in the rumen and reticulum and activate the satiety center (Allen, 2000).

In agreement with our results, DeFrain et al. (2004) and Chung et al. (2007), evaluating lactating cattle fed high-forage diets, also reported no effects on feed intake when CG was added to the diet at 0.86 and 0.250 $\mathrm{kg} / \mathrm{d}$ respectively, levels similar to those employed in the present study. However, other authors described a linear decrease in DMI with increasing concentrations of glycerol in the diet (Musselman et al., 2008; Gunn et al., 2010). The reason underlying this contrast is related to the greater concentrations of CG $(450 \mathrm{~g} / \mathrm{kg}$ of DM) used in these studies in comparison with the concentration employed in the present study (55.6 $\mathrm{g} / \mathrm{kg}$ of DM).

Supplementation with CG in the diet of young bulls in pasture did not alter nutrient digestibility. This result is in contrast to those of Wang et al. (2009), who found in steers a linear increase of nutrient digestibility with increased glycerol concentration. However, in the above study glycerin was added to a standard diet provided to animals, resulting in diets with different amounts of energy; in the present study we replaced corn for $\mathrm{CG}$, resulting in isocaloric diets.

Corn replacement with $\mathrm{CG}$ did not affect fiber digestion. To clarify the observed numerical variation in the digestibility of NDF, we speculate that CG at lower concentrations ( 1 to $10 \mathrm{~g} / \mathrm{kg} \mathrm{DM}$ diet) has no effect on growth, adhesion, and cellulolytic activity. However, at the greatest concentration used $(50 \mathrm{~g} / \mathrm{kg})$, it begins inhibiting growth and cellulolytic bacteria activity (Roger et al., 1992). Hess et al. (2008) reported that the addition of CG up to $150 \mathrm{~g} / \mathrm{kg}$ DM in ruminant diets also did not affect DM or fiber digestibility of warm-season grasses, which decreased only when glycerin concentrations surpassed $150 \mathrm{~g} / \mathrm{kg}$ DM. In another study, increasing concentrations of glycerol to lucerne (Medicago sativa) hay in vitro also did not affect NDF degradability (Krueger et al., 2010). However, reduction in fiber digestion was reported when glycerol was added to starch-containing diets in vivo (Schröder and Südekum, 1999) and in vitro (Abo El-Nor et al., 2010)

The discrepancies between studies on the effects of glycerol in nutrient digestibility are difficult to explain. According to Lee et al. (2011), a possible interaction between dietary components and CG addition results in different responses by microbe species and products of fermentation. 
Table 4. Effect of level of crude glycerin (CG) inclusion in the supplement on VFA concentrations of Nellore steers grazing tropical grass

\begin{tabular}{|c|c|c|c|c|c|c|c|c|c|}
\hline \multirow[b]{3}{*}{ Item } & \multicolumn{5}{|c|}{ CG in the supplement, $\mathrm{g} / \mathrm{kg} \mathrm{DM}$} & \multirow[b]{3}{*}{ SEM } & \multicolumn{3}{|c|}{$P$-value } \\
\hline & \multirow[b]{2}{*}{0} & \multirow[b]{2}{*}{70} & \multirow[b]{2}{*}{140} & \multirow[b]{2}{*}{210} & \multirow[b]{2}{*}{280} & & \multirow[b]{2}{*}{ Supplement } & \multicolumn{2}{|c|}{ Contrast $^{1}$} \\
\hline & & & & & & & & $\mathrm{L}$ & $\mathrm{Q}$ \\
\hline Total VFA, $\mathrm{m} M$ & 114.3 & 113.1 & 114.2 & 114.8 & 108.7 & 4.9 & 0.07 & 0.29 & 0.32 \\
\hline Acetate, ${ }^{2} \%$ & 70.0 & 68.7 & 68.4 & 67.0 & 65.6 & 0.57 & 0.001 & 0.001 & 0.37 \\
\hline Propionate, $\%$ & 16.7 & 16.6 & 17.1 & 17.1 & 18.1 & 0.39 & 0.015 & 0.001 & 0.18 \\
\hline Butyrate, $\%$ & 9.8 & 11.0 & 10.6 & 12.0 & 12.4 & 0.38 & 0.001 & 0.001 & 0.83 \\
\hline Isobutyrate, $\%$ & 1.08 & 1.05 & 1.14 & 1.04 & 1.05 & 0.07 & 0.63 & 0.61 & 0.55 \\
\hline Valerate, $\%$ & 0.82 & 0.94 & 0.97 & 1.07 & 1.18 & 0.03 & 0.001 & 0.001 & 0.62 \\
\hline Isovalerate, $\%$ & 1.4 & 1.5 & 1.6 & 1.5 & 1.5 & 0.07 & 0.31 & 0.28 & 0.19 \\
\hline A:P ratio, ${ }^{3} \%$ & 4.2 & 4.0 & 4.0 & 4.0 & 3.7 & 0.10 & 0.007 & 0.001 & 0.37 \\
\hline
\end{tabular}

In relation to the rumen short-chain fatty acids, the decrease in the molar proportion of acetate is somewhat expected because $\mathrm{CG}$ is commonly converted to propionate in the rumen (Rémond et al., 1993). In the present study acetate decreased, whereas the molar proportion of propionate, butyrate, and valerate increased. The increase of molar proportion of butyrate and valerate may have resulted from an increase in the production of lactate by fermentation of CG (Trabue et al., 2007) that provided a substrate for Megasphaera elsdenii (Klieve et al., 2003), which is known to produce these VFA.

The increase in molar proportion of propionate indicates that glycerol is mostly fermented into propionate in the rumen. This fact is consistent with other studies (Shin et al., 2012; DeFrain et al., 2004) that found that animals supplemented with glycerol had greater rumen molar proportions of propionate. Thus, although we did not measure the VFA production, only the concentration and molar proportion, our results confirm the propiogenic properties of glycerol and support the possible suppression effect of glycerol on acetate formation in the rumen found by Trabue et al. (2007).

The lack of an effect of CG inclusion on final BW, LM area, RFT, and CrG is most likely explained by the lack of a difference in DMI between treatments, assuming that supplementation remained isocaloric and isonitrogenous, and by the low level of CG inclusion in the $\operatorname{diet}(55.6 \mathrm{~g} / \mathrm{kg} \mathrm{DM})$. Compared with the control, G:F and ADG increased by $26.66 \%$ and $6.65 \%$, respectively, at the concentration of $210 \mathrm{~g} / \mathrm{kg}$ of CG inclusion. The ADG increase and feed efficiency improvement may be the result of a lower proportion of NDF and higher proportion of NFC with the increase of CG in the supplement. Thus, in animals consuming an isocaloric supplement, increasing levels of $\mathrm{CG}$ allowed better utilization of the diet consumed by the animals, resulting in greater ADG. The improvement of G:F found herein is corroborated by the studies of Parsons et al. (2009) and Ramos and Kerley (2011), who found positive effects on G:F when CG replaced corn by up to 100 and $200 \mathrm{~g} / \mathrm{kg}$ of the diet DM.

In this study, CG concentration of up to $280 \mathrm{~g} / \mathrm{kg}$ DM of supplement ( $50 \mathrm{~g} / \mathrm{kg}$ of DM diet) did not result in altering RFT values. In agreement with our results, Mach et al. (2009) and Barton et al. (2013) reported that replacement of barley with glycerin concentrations up to 120 and $100 \mathrm{~g} / \mathrm{kg} \mathrm{DM}$, respectively, did not affect carcass traits of cattle, including RFT. These results were somewhat unexpected. It is known that glycerin is an important gluconeogenic substrate, being one of the main lipid precursors of intramuscular adipose tissue (Smith and Crouse, 1984; Smith et al., 2009). However, the increase in the molar proportion of propionate, butyrate, and valerate does not affect the i.m. and s.c. fat deposition. Because acetic acid is the main precursor of lipogenesis, it was therefore expected that inclusion of glycerin would reduce s.c. fat, which did not occur.

The replacement of corn grain with CG in the supplement provided to grass-fed young Nellore bulls did not change $\mathrm{CH}_{4}$ emission. In this study, the mean calculated value of enteric $\mathrm{CH}_{4}$ emission for the treatments used here was $48.8 \mathrm{~kg} \mathrm{CH}_{4} / \mathrm{yr}$. This estimate is less than the estimate of $56 \mathrm{~kg} \mathrm{CH}_{4} / \mathrm{yr}$ made by the Intergovernmental Panel on Climate Change (2006) for cattle.

The strategy of using glycerol to reduce $\mathrm{CH}_{4}$ production was verified by Lee et al. (2011), who evaluated the use of coincubation of glycerol with alfalfa or corn in vitro. They found that glycerol addition decreased $\mathrm{CH}_{4}$ production by $25.2 \%$ and $14.8 \%$ in alfalfa and corn assays, respectively. The mitigation of ruminal methanogenesis mediated by glycerol may be achieved by the propiogenic properties of glycerol, obtained by favoring the propionate production, causing a decrease in the supply of hydrogen to methanogenic bacteria (Morgavi et al., 2010). However, in the 
Table 5. Effect of supplements containing different crude glycerin (CG) concentration on methane emission of Nellore bulls in pasture

\begin{tabular}{|c|c|c|c|c|c|c|c|c|c|}
\hline \multirow[b]{3}{*}{ Item $^{1}$} & \multicolumn{5}{|c|}{ CG in the supplement, $g / \mathrm{kg} D M$} & \multirow[b]{3}{*}{ SEM } & \multicolumn{3}{|c|}{$P$-value ${ }^{2}$} \\
\hline & \multirow[b]{2}{*}{0} & \multirow[b]{2}{*}{70} & \multirow[b]{2}{*}{140} & \multirow[b]{2}{*}{210} & \multirow[b]{2}{*}{280} & & \multirow[b]{2}{*}{ Supplement } & \multicolumn{2}{|c|}{ Contrasts $^{3}$} \\
\hline & & & & & & & & $\mathrm{L}$ & $\mathrm{Q}$ \\
\hline $\mathrm{CH}_{4}, \mathrm{~g} \cdot$ animal $^{-1} \cdot \mathrm{d}^{-1}$ & 125.5 & 143.6 & 137.5 & 142.3 & 121.1 & 32.1 & 0.74 & 0.82 & 0.22 \\
\hline $\mathrm{CH}_{4}, \mathrm{~kg} \cdot \operatorname{animal}^{-1} \cdot \mathrm{yr}^{-1}$ & 45.8 & 52.4 & 50.1 & 51.9 & 44.2 & 11.7 & 0.74 & 0.82 & 0.22 \\
\hline $\mathrm{CH}_{4}, \mathrm{~g} / \mathrm{kg}$ DMI & 11.2 & 12.7 & 13.1 & 13.7 & 11.5 & 3.3 & 0.69 & 0.72 & 0.20 \\
\hline $\mathrm{CH}_{4}, \mathrm{~g} / \mathrm{kg}$ DNDFI & 43.4 & 48.8 & 53.1 & 57.0 & 47.9 & 12.1 & 0.42 & 0.30 & 0.15 \\
\hline $\mathrm{CH}_{4}, \%$ GEI & 3.4 & 3.9 & 3.9 & 4.1 & 3.5 & 1.0 & 0.76 & 0.74 & 0.23 \\
\hline $\mathrm{CH}_{4}, \mathrm{~g} / \mathrm{kg} \mathrm{CrG}$ & 241.3 & 312.2 & 286.2 & 269.2 & 226.6 & 76.3 & 0.48 & 0.51 & 0.11 \\
\hline
\end{tabular}

${ }^{1} \mathrm{DNDFI}=$ digestible NDF intake; $\mathrm{GEI}=\mathrm{GE}$ intake; $\mathrm{CrG}=$ carcass gain.

${ }^{2}$ Significant at $P>0.05$.

${ }^{3}$ Contrasts: $\mathrm{L}=$ linear, $\mathrm{Q}=$ quadratic.

present study the inclusion of CG in the supplement increased the molar proportion of propionic and butyric acid but did not affect the $\mathrm{CH}_{4}$ emission.

In contrast to the aforementioned studies, other studies show an increase in $\mathrm{CH}_{4}$ production with the inclusion of glycerol in the substrate, mainly in vitro. Indeed, with increasing concentrations of glycerol in forage-based diets in vitro, $\mathrm{CH}_{4}$ concentrations in gas and total $\mathrm{CH}_{4}$ production per unit of DM increased, suggesting that fermentation of glycerol to propionate did not act as a hydrogen sink (Avila et al., 2013).

The conflicting results regarding the effect of glycerol on $\mathrm{CH}_{4}$ production is probably due to the lack of steps toward the adaptation of animals to diets containing glycerol in in vitro experiments. Indeed, gas and $\mathrm{CH}_{4}$ production increased when $150 \mathrm{~g} / \mathrm{kg}$ glycerol were included in the substrates using inoculum obtained from glycerol-adapted animals. However, changes in $\mathrm{CH}_{4}$ production were negligible when the inoculum was obtained from unadapted animals (van Cleef et al., 2011). These results suggest that ruminal microbial adaptation affects digestion and fermentation of glycerol end products. Another explanation for the increase in $\mathrm{CH}_{4}$ production with glycerol is based on the equimolar conversion of glycerol to formate and ethanol. Formate is a precursor of $\mathrm{CH}_{4}$ (Hungate et al., 1970), and large amounts of ethanol are oxidized to acetate in the rumen (Pradhan and Hemken, 1970; Jean-Blain et al., 1992), a process that releases reducing equivalents that can be used for $\mathrm{CH}_{4}$ production (Moomaw and Hungate, 1963).

In summary, this study revealed that $C G$ in the supplementation of forage-based diets did not affect $\mathrm{CH}_{4}$ emission in young Nellore bulls, probably because of the low level of CG used in diet (5\%). Values for average energy lost in the form of $\mathrm{CH}_{4}$ emissions similar to those found in this study were recently presented by Neto et al. (2015), corroborating the fact that well-managed tropical pastures with the proper use of animal supplementation can improve performance and reduce energy losses in the system.

The use of CG was not effective as a strategy to reduce methane emissions in cattle raised on pasture on the basis of the conditions and supplementation levels of this experiment. However, $\mathrm{CG}$ as a replacement for corn grain improved gain and feed efficiency at $210 \mathrm{~g} \mathrm{CG} / \mathrm{kg}$ of supplement in grass-fed young Nellore bulls. Thus, CG is promising as a feedstuff for cattle raised on pasture.

\section{LITERATURE CITED}

Abo El-Nor, S., A. A. Abughazaleh, R. B. Potu, D. Hastings, and M. S. A. Khattab. 2010. Effect of differing levels of glycerol on rumen fermentation and bacteria. Anim. Feed Sci. Technol. 162:99-105. doi:10.1016/j.anifeedsci.2010.09.012

ActionAid International USA. 2012. Fueling the food crisis: The cost to developing countries of US corn ethanol expansion. ActionAid Int. USA, Washington, DC.

Allen, M. S. 2000. Effects of diet on short-term regulation of feed intake by lactating dairy cattle. J. Dairy Sci. 83:1598-1624. doi:10.3168/jds.S0022-0302(00)75030-2

Allen, M. S., and B. J. Bradford. 2009. Metabolic regulation of feed intake in cattle: A conceptual model. J. Anim. Sci. 87:33173334. doi: $10.2527 /$ jas.2009-1779

Allen, V. G., C. Batello, E. J. Berretta, J. Hodgson, M. Kothmann, X. Li, J. Mclvor, J. Milne, C. Morris, A. Peeters, and M. Sanderson. 2011. An international terminology for grazing lands and grazing animals. Grass Forage Sci. 66:2-28. doi:10.1111/j.13652494.2010.00780.x

AOAC. 1995. Official methods of analysis, 16th ed. Assoc. Off. Anal. Chem., Arlington, VA.

Avila, S. J., A. V. Chaves, G. O. J. Ribeiro, E. M. Ungerfeld, and T. A. McAllister. 2013. Inclusion of glycerol in forage diets increases methane production in a rumen technique system. Br. J. Nutr. 7:1-7. doi:10.1017/S0007114513003206

Barthram, G. T. 1985. Experimental techniques: The HFRO sward stick In: The hill farming research organization biennial report 1984/1985. Hill Farming Res. Organ., Penicuik, UK. p. 29-30.

Bartoň, L., D. Bureš, P. Homolka, F. Jančík, M. Marounek, and D. Řehák. 2013. Effects of long-term feeding of crude glycerine on performance, carcass traits, meat quality, and blood and rumen metabolites of finishing bulls. Livest. Sci. 155:53-59. doi:10.1016/j.livsci.2013.04.010 
Boadi, D., C. Benchaar, J. Chiquette, and D. Massé. 2004. Mitigation strategies to reduce enteric methane emissions from dairy cows: Update review. Can. J. Anim. Sci. 84:319-335. doi:10.4141/ A03-109

Chung, Y. H., D. E. Rico, C. M. Martinez, T. W. Cassidy, V. Noirot, A. Ames, and G. A. Varga. 2007. Effects of feeding dry glycerin to early postpartum Holstein dairy cows on lactational performance and metabolic profiles. J. Dairy Sci. 90:5682-5691. doi:10.3168/jds.2007-0426

DeFrain, J. M., A. R. Hippen, K. F. Kalscheur, and P. W. Jardon. 2004. Feeding glycerol to transition dairy cows: Effects on blood metabolites and lactation performance. J. Dairy Sci. 87:4195-4206. doi:10.3168/jds.S0022-0302(04)73564-X

Gerber, P. J., H. Steinfeld, B. Henderson, A. Mottet, C. Opio, J. Dijkman, A. Falcucci, and G. Tempio. 2013. Tackling climate change through livestock: A global assessment of emissions and mitigation opportunities. Food Agric. Organ. UN, Rome.

Greiner, S. P., G. H. Rouse, D. E. Wilson, L. V. Cundiff, and T. L. Wheeler. 2003. The relationship between ultrasound measurements and carcass fat thickness and longissimus muscle area in beef cattle. J.Anim. Sci. 81:676-682. doi:10.2527/2003.813676x

Gunn, P. J., A. F. Schultz, M. L. Van Emon, M. K. Neary, R. P. Lemenager, C. P. Rusk, and S. Lake. 2010. Effects of elevated crude glycerin concentrations on feedlot performance, carcass characteristics, and metabolite and hormone concentrations in finishing ewe and wether lambs. Prof. Anim. Sci. 26:298-306.

HALL, M. B. 2000. Calculation of non-structural carbohydrate content of feeds that contain non-protein nitrogen. Gainesville: University of Florida, 2000. p.A-25 (Bulletin, 339).

Hales, K. E., R. G. Bondurant, M. K. Luebbe, N. A. Cole, and J. C. MacDonald. 2013. Effects of crude glycerin in steam-flaked corn-based diets fed to growing feedlot cattle. J. Anim. Sci. 91:3875-3880. doi:10.2527/jas.2012-5944

Hess, B. W., G. E. Moss, and D. C. Hule. 2008. A decade of developments in the area of fat supplementation research with beef cattle and sheep. J. Anim. Sci. 86:E188-E204. doi:10.2527/jas.20070546

Hungate, R. E., W. Smith, T. Bouchop, I. Yu, and J. C. Rabinowitz. 1970. Formate as an intermediate in the bovine rumen fermentation. J. Bacteriol. 102:389-397.

Intergovernmental Panel on Climate Change. 2006. Emissions from livestock and manure management. In: Guidelines for national greenhouse inventories, Vol. 4, Agriculture, Forestry and Other Land Use. Inst. Global Environ. Strategies, Hayama, Japan. P. 10.1-10.87.

Jean-Blain, C., A. Durix, and B. Tranchant. 1992. Kinetics of ethanol metabolism in sheep. Reprod. Nutr. Dev. 32:83-90. doi:10.1051/ rnd:19920109

Johnson, A. D. 1978. Sample preparation and chemical analysis of vegetation. In: L. T. Manejte, editor, Measurement of grassland vegetation and animal production. Commonweath Agricultural Bureax, Aberustwysth, UK. p. 96-102.

Johnson, K., M. Huyler, H. Westberg, B. Lamb, and P. Zimmerman. 1994. Measurement of methane emissions from ruminant livestock using a sulfur hexafluoride tracer technique. Environ. Sci. Technol. 28:359-362. doi:10.1021/es00051a025

Klieve, A. V., D. Hennessy, D. Ouwerkerk, R. J. Forster, R. I. Mackie, and G. T. Attwood. 2003. Establishing populations of Megasphaera elsdenii YE 34 and Butyrivibrio fibrisolvens YE 44 in the rumen of cattle fed high grain diets. J. Appl. Microbiol. 95:621-630. doi:10.1046/j.1365-2672.2003.02024.x

Krehbiel, C. R. 2008. Ruminal and physiological metabolins of glycerin. J. Anim. Sci. 86(Suppl.):392.
Krueger, N. A., R. C. Anderson, L. O. Tedeschi, T. R. Callaway, T. S. Edrington, and D. J. Nisbet. 2010. Evaluation of feeding glycerol on free-fatty acid production and fermentation kinetics of mixed ruminal microbes in vitro. Bioresour. Technol. 101:84698472. doi:10.1016/j.biortech.2010.06.010

Lee, S. Y., S. M. Lee, Y. B. Cho, D. K. Kam, S. C. Lee, C. H. Kim, and S. Seo. 2011. Glycerol as a feed supplement for ruminants: In vitro fermentation characteristics and methane production. Anim. Feed Sci. Technol. 166-167:269-274. doi:10.1016/j.anifeedsci.2011.04.070

Mach, N., A. Bach, and M. Devant. 2009. Effects of crude glycerin supplementation on performance and meat quality of Holstein bulls fed high-concentrate diets. J. Anim. Sci. 87:632-638. doi:10.2527/jas.2008-0987

McAllister, T. A., and C. J. Newbold. 2008. Redirecting rumen fermentation to reduce methanogenesis. Aust. J. Exp. Agric. 48:713. doi:10.1071/EA07218

Ministério da Agricultura, Pecuária e Abastecimento. 1997. Regulamento da Inspeção Industrial e Sanitária de Produtos de Origem Animal [Food of animal origin sanitary and industry inspection]. Minist. Agric. Pecu. Abastecimento, Brasília.

Moomaw, C. R., and R. E. Hungate. 1963. Ethanol conversion in the bovine rumen. J. Bacteriol. 85:721-722.

Morgavi, D. P., E. Forano, C. Martin, and C. J. Mewbold. 2010. Microbial ecosystem and methanogenesis in ruminants. Animal 4:1024-1036. doi:10.1017/S1751731110000546

Musselman, A. F., M. L. Van Emon, P. J. Gunn, C. P. Rusk, M. K. Neary, R. P. Lemenager, and S. L. Lake. 2008. Effects of crude glycerin on feedlot performance and carcass characteristics of market lambs. Proc. West. Sect. Am. Soc. Anim. Sci. 59:353355.

Neto, A. J., J. D. Messana, A. F. Ribeiro, E. San Vito, L. G. Rossi, and T. T. Berchielli. 2015. Effect of starch-based supplementation level combined with oil on intake, performance, and methane emissions of growing Nellore bulls on pasture. J. Anim. Sci. 93(5):2275-2284. doi:10.2527/jas.2014-8500

NRC. 2001. Nutrient requirements of dairy cattle. 7th rev. ed. Natl. Acad. Press, Washington, DC, USA

Parsons, G. L., M. K. Shelor, and J. S. Drouillard. 2009. Performance and carcass traits of finishing heifers fed crude glycerin. J. Anim. Sci. 87:653-657. doi:10.2527/jas.2008-1053

Pradhan, K., and R. W. Hemken. 1970. Utilization of ethanol and its effect on fatty acid patterns in ruminants. J. Dairy Sci. 53:17391746. doi:10.3168/jds.S0022-0302(70)86472-4

Ramos, M. H., and M. S. Kerley. 2011. Effect of dietary crude glycerin level on ruminal fermentation in continuous culture and growth performance of beef calves. J. Anim. Sci. 90:892-899. doi:10.2527/jas.2011-4099

Reis, R. A., A. C. Ruggieri, D. R. Casagrande, and A. G. Páscoa. 2009. Suplementação da dieta de bovinos de corte como estratégia do manejo das pastagens. Rev. Bras. Zootec. 38:147-159. doi:10.1590/S1516-35982009001300016

Rémond, B., E. Souday, and J. P. Jouany. 1993. In vitro and in vivo fermentation of glycerol by rumen microbes. Anim. Feed Sci. Technol. 41:121-132. doi:10.1016/0377-8401(93)90118-4

Roger, V., G. Fonty, C. Andre, and P. Gouet. 1992. Effects of glycerol on the growth, adhesion, and cellulolytic activity of rumen cellulolytic bacteria and anaerobic fungi. Curr. Microbiol. 25:197201. doi:10.1007/BF01570719 
Saliba, E. O. S., N. C. Gonçalves, G. S. S. C. Barbosa, A. L. C. C. Borges, N. M. Rodriguez, G. R. Moreira, and F. A. Silva. 2013. Evaluation of the infrared spectroscopy method for the quantification of nanolipe marker in feces of dairy cattle. In: J. W. Oltjen, E. Kebreab, and H. Lapierre, editors, Energy and protein metabolism and nutrition in sustainable animal production. Wageningen Acad. Publ., Wageningen, The Netherlands. p. 247 248. doi:10.3920/978-90-8686-781-3_81

Santos, S. A., S. C. V. Filho, E. Detmann, R. F. D. Valadares, J. R. M. Ruas, and P. M. Amaral. 2011. Different forage sources for F1 Holstein $\times$ Gir dairy cows. Livest. Sci. 142:48-58. doi:10.1016/j. livsci.2011.06.017

Schröder, A., and K. H. Südekum. 1999. Glycerol as a by-product of biodiesel production in diets for ruminants. In: N. Wratten and P. A. Salisbury, editors, New horizons for an old crop: Proc. 10th Int. Rapeseed Congr. Regional Inst., Gosford, NSW, Australia. Paper No. 241.

Smith, S. B., and J. D. Crouse. 1984. Relative contribution of acetate, lactate and glucose to lipogenesis in bovine intramuscular and subcutaneous adipose tissue. J. Nutr. 114:792-800.

Smith, S. B., H. Kawachi, C. B. Choi, C. W. Choi, G. Wu, and J. E. Sawyer. 2009. Cellular regulation of bovine intramuscular adipose tissue development and composition. J. Anim. Sci. 87(Suppl.):E72-E82. doi:10.2527/jas.2008-1340

Shin, J. H., D. Wang, S. C. Kim, A. T. Adesogan, and C. R. Staples. 2012. Effects of feeding crude glycerin on performance and ruminal kinetics of lactating Holstein cows fed corn silage- or cottonseed hull-based, low-fiber diets. J. Dairy Sci. 95:4006-4016. doi:10.3168/jds.2011-5121
Trabue, S., K. Scoggin, S. Tjandrakusuma, M. A. Rasmussen, and P. J. Reilly. 2007. Ruminal fermentation of propylene glycol and glycerol. J. Agric. Food Chem. 55:7043-7051. doi:10.1021/ jf071076i

Valente, T. N. P., E. Detmann, A. C. Queiroz, S. C. Valadares Filho, D. I. Gomes, and J. F. Figueiras. 2011. Evaluation of ruminal degradation profiles of forages using bags made from different textiles. Rev. Bras. Zootec. 40:2565-2573. doi:10.1590/S151635982011001100039

van Cleef, E. H., S. Uwituze, and J. S. Drouillard. 2011. Effects of crude glycerin on in vitro gas production, dry matter disappearance, VFA profiles, and composition of fermentative gasses. J. Anim. Sci. 89, E-Suppl. 1 : 613.

Van Soest, P. J., J. B. Robertson, and B. A. Lew. 1991. Methods for dietary fiber, neutral detergent fiber, and nonstarch polysaccharides in relation to animal nutrition. J. Dairy Sci. 74:3583-3597. doi:10.3168/jds.S0022-0302(91)78551-2

Wang, C., Q. Lui, W. J. Huo, W. Z. Yang, K. H. Dong, Y. X. Huang, and G. Guo. 2009. Effects of feeding glycerol on rumen fermentation, urinary excretion of purine derivatives and feed digestibility in steers. Livest. Sci. 121:15-20. doi:10.1016/j. livsci.2008.05.010

Westberg, H. H., K. A. Johnson, M. W. Cossalman, and J. J. Michael. 1998. A SF 6 tracer technique: Methane measurement from ruminants. Washington State University, Pullman. 40. 